\title{
Opposite changes in cerebellar vs. cortical blood brain barrier (BBB) expression in aged and hydrocephalic rats
}

\author{
Petra M Klinge*1, Arthur Messier ${ }^{2}$, Anna Heile ${ }^{1}$, Mohsen Nouri ${ }^{1}$, \\ Conrad E Johanson ${ }^{2}$, John A Duncan ${ }^{2}$, Thomas Brinker ${ }^{1}$ and \\ Gerald D Silverberg ${ }^{2}$
}

\author{
Address: ${ }^{1}$ Department of Neurosurgery, International Neuroscience Institute, Hanover 30625, Germany and ${ }^{2}$ Department of Clinical \\ Neuroscience, Brown University, Providence, RI 02903, USA \\ Email: Petra M Klinge* - pmklinge@gmail.com \\ * Corresponding author
}

from $\left.5\right|^{\text {st }}$ Annual Meeting of the Society for Research into Hydrocephalus and Spina Bifida Heidelberg, Germany. 27-30 June 2007

Published: 20 December 2007

Cerebrospinal Fluid Research 2007, 4(Suppl I):S4 doi:I0.II86/I743-8454-4-SI-S4

This abstract is available from: http://www.cerebrospinalfluidresearch.com/content/4/SI/S4

(c) 2007 Klinge et al; licensee BioMed Central Ltd.

\section{Background}

Little is known about the cerebellum in NPH. Studies show that neurotransmitter changes in the cerebellum are opposite to the cortex $[1,2]$. In Kaolin-induced hydrocephalus, increases of A-beta peptides at cortical and hippocampal microvessels were found [3]. Reciprocal changes in BBB receptors, LRP-1, which transports A-beta out of, and RAGE, which transports A-beta into the brain, indicated a defective clearance might be causal. We looked at LRP-1 and RAGE expression changes in the cerebellum vs. the cortex in hydrocephalic and aged rats.

\section{Materials and methods}

In Brown-Norway/Fisher (BN/F) rats, Western blots(WB) of the BBB transporters LRP-1 and RAGE were performed in the cortex, cerebellum and in microvessel preparations, $\mathrm{N}=8$ at ages 3 (young), 12 (mid-aged) and 36 months (senescent). In fifteen 12 months-old Sprague-Dawley (SD) rats with Kaolin-induced hydrocephalus, cortical and cerebellar cryosections were investigated by specific A-beta42, LRP-1 and RAGE antibody immunohistochemistry (ICH), performed 2, 6 and 10 weeks post induction.

\section{Results}

In the BN/Frats, cortical and hippocampal tissue and microvessel WB of LRP-1 at 12 and 36 months showed a loss at the LRP-1 kDa range, compared to 3 mos. rats. In the cerebellum, however, there was a 3-fold increase of positive WB staining at 36 mos compared to 3 mos. For the RAGE blot at 3 mos, the amount in cerebellum at about 42-45 $\mathrm{kDa}$ was greater than in the cortex. In the hydrocephalic rats, parenchymal as well as perivascular Abeta stained accumulations were observed in the cerebellar molecular layer, and significantly increased up to 10weeks of hydrocephalus (Mann-Whitney-U). LRP-1 stained microvessel counts showed decreases $(\mathrm{n} / \times 40$ microscopic field) at 2, 6 and 10 weeks, however, to a lesser degree than observed in the cortex and the hippocampus (ANOVA, p > 0.05). Different from changes seen in the cortex, cerebellar RAGE microvessel staining was decreased at 10 weeks compared to the age-matched controls (ANOVA, $\mathrm{p}<0.01$ ), and correlation between the amount of stained amyloid and RAGE vessel count was negative $(-0,469, \mathrm{p}<0.05)$.

\section{Conclusion}

Qualitatively and quantitatively, the BBB receptor expression in the cerebellum appears to be opposite to that in the cortex in ageing rats. Different from cerebellar changes seen in the ageing rat model, and different from A-beta/ BBB receptor relationships seen in the cortex, in hydrocephalus, the cerebellar LRP-1 vessel staining mirrored the cortical changes while the RAGE opposed them. The find- 
ings might indicate a role for "remote" mechanisms in the cerebellum in hydrocephalus.

\section{References}

I. Kondziella D, Ludemann W, Brinker T, Sletvold O, Sonnewald U: Alterations in brain metabolism, CNS morphology and CSF dynamics in adult rats with kaolin-induced hydrocephalus. Brain Res 2002, 927:35-4I.

2. Miwa S, Inagaki C, Fujiwara M, Takaori S: The activities of noradrenergic and dopaminergic neurone systemsin experimental hydrocephalus. J Neurosurg 1982, 57:67-73.

3. Klinge PM, Samii A, Niescken S, Brinker T, Silverberg GD: Brain amyloid accumulates in aged rats with kaolin-induced hydrocephalus. NeuroReport 2006, 17:657-660.

Publish with Biomed Central and every scientist can read your work free of charge

"BioMed Central will be the most significant development for disseminating the results of biomedical research in our lifetime. "

Sir Paul Nurse, Cancer Research UK

Your research papers will be:

- available free of charge to the entire biomedical community

- peer reviewed and published immediately upon acceptance

- cited in PubMed and archived on PubMed Central

- yours - you keep the copyright 